\title{
Plasma Carboxypeptidases as Regulators of the Plasminogen System
}

\author{
Alexander Redlitz, * Anthony K. Tan, ${ }^{\ddagger}$ Dan L. Eaton, ${ }^{\ddagger}$ and Edward F. Plow * \\ *Center for Thrombosis and Vascular Biology/FF20, Department of Molecular Cardiology, Cleveland Clinic Foundation, Cleveland, \\ Ohio 44195; and ${ }^{\ddagger}$ Genentech Inc., Department of Cardiovascular Research, South San Francisco, California 94080
}

\begin{abstract}
Carboxy-terminal lysine residues on the surface of cells and fibrin bind plasminogen and control its activation. Since plasma contains basic carboxypeptidases, which remove carboxy-terminal lysines from protein substrates, we investigated if these enzymes are involved in the regulation of plasminogen binding sites. Plasma reduced plasminogen binding to cells, and this effect could be ascribed to the activity of the plasma carboxypeptidases. Purified carboxypeptidase $\mathbf{N}$, which is constitutively active, and plasma carboxypeptidase $B$, which circulates as a zymogen, were both capable of significantly reducing plasminogen binding to cells. Dose titration experiments verified that plasma concentrations of either carboxypeptidase were sufficient to maximally affect plasminogen binding to cells. Furthermore, plasma carboxypeptidase $B$, but not carboxypeptidase $N$, reduced the rate of whole blood clot lysis induced by tissue-type plasminogen activator. These findings establish that plasma carboxypeptidases can modulate plasminogen binding to cells and control the rate of fibrinolysis. These functions delineate a novel role for the plasma carboxypeptidases in the regulation of the plasminogen system. (J. Clin. Invest. 1995. 96:2534-2538.) Key words: fibrinolysis • plasminogen activation • thrombolysis $\cdot$ plasminogen receptors
\end{abstract}

\section{Introduction}

Surfaces, either fibrin or cell surfaces, play a pivotal role in the regulation of the plasminogen system (for reviews see references 1 and 2). Surface-bound plasminogen is a better substrate for plasminogen activators, and bound plasmin is protected from rapid inactivation by $\alpha_{2}$-antiplasmin $(3,4)$. Interaction of plas$\min$ (ogen) with surfaces is largely dependent upon the recognition of carboxy-terminal lysyl residues by the lysine binding sites associated with the kringle structures of plasminogen (5). Such lysines may exist as the naturally occurring carboxy termini of proteins or may arise as a result of limited proteolysis by enzymes including plasmin (6-11). The latter mechanism

Address correspondence to A. Redlitz, Center for Thrombosis and Vascular Biology/FF20, Cleveland Clinic Foundation, 9500 Euclid Avenue, Cleveland, $\mathrm{OH}$ 44195. Phone: 216-445-8213; FAX: 216-445-8204.

Received for publication 14 May 1995 and accepted in revised form 26 July 1995.

J. Clin. Invest.

(C) The American Society for Clinical Investigation, Inc.

0021-9738/95/11/2534/05 $\$ 2.00$

Volume 96, November 1995, 2534-2538 provides a positive feedback loop in which plasmin cleavage of cell surface proteins or fibrin up-regulates binding sites for plasminogen which favor further plasmin formation. Carboxyterminal lysines are sensitive to exo-proteinases, such as pancreatic carboxypeptidase $(\mathrm{Cp})^{1} \mathrm{~B}$, an enzyme which removes basic carboxy-terminal amino acids (lysines and arginines) from proteins. Indeed, Cp B has been used to implicate carboxy-terminal lysines in plasminogen binding to cells (5) and to partially plasmin-degraded fibrin $(9,11,12)$.

Enzymes with a cleavage specificity similar to $\mathrm{Cp} B$ are present in blood. $\mathrm{Cp} \mathrm{N}$ accounts for the constitutive $\mathrm{Cp}$ activity of plasma and is involved in the metabolism of numerous circulating peptides (for review see reference 13). Plasma Cp B ( $\mathrm{pCPB}$ ), which is structurally very similar to tissue $\mathrm{Cp} \mathrm{B}$, circulates as a proenzyme and is activated by plasmin and thrombin (14). Cp U is a basic Cp-activity that is detected in serum following coagulation (15). It has been suggested that pCPB contributes to $\mathrm{Cp} \mathrm{U}$ because of functional similarities (16).

The existence of $\mathrm{Cp}$ activity in blood raises the possibility that these enzymes may influence plasminogen binding to surfaces. Using plasminogen binding to cell lines of leukocyte origin as a model system, we show that both $\mathrm{Cp} \mathrm{N}$ and pCPB are potent modulators of plasminogen binding to these cells. Additionally, lysis of whole blood clots is significantly inhibited by $\mathrm{pCPB}$. Taken together, these observations provide the basis to suggest a novel role for the basic $\mathrm{Cp}$ of plasma in the regulation of the plasminogen system.

\section{Methods}

Enzyme assays. Basic Cp-activity was measured with furoylacroleylalanyl-lysine (lysine substrate) or furoylacroleyl-alanyl-arginine (arginine substrate) (both from Bachem, Philadelphia, PA) as substrates (17, 18). Test samples, diluted to $200 \mu \mathrm{l}$ with $0.9 \% \mathrm{NaCl}$, were added to $300 \mu \mathrm{l}$ of $0.5 \mathrm{mM}$ substrate in $100 \mathrm{mM}$ Hepes, $150 \mathrm{mM} \mathrm{NaCl}, \mathrm{pH} \mathrm{7.2,}$ and the decrease in absorbance at $336 \mathrm{~nm}$ was measured. Plasmin activity was determined with the chromogenic substrate S2251 (Chromogenix, Molndal, Sweden) in $100 \mathrm{mM}$ Hepes, $150 \mathrm{mM} \mathrm{NaCl}, \mathrm{pH}$ 7.2. Both assays were performed at $22^{\circ} \mathrm{C}$. Enzyme activity was expressed as substrate conversion: $1 \mathrm{U}=1 \mu \mathrm{mol} / \mathrm{min}$ under the conditions of the assays.

Carboxypeptidases. $\mathrm{Cp} \mathrm{N}$ was purified from fresh citrated human plasma $(19,20)$. Isolated $\mathrm{Cp} \mathrm{N}$ displayed appropriate properties compared to described preparations (21), including a similar purification factor (5780) and specific activity (27 U/mg, lysine substrate), a four-

1. Abbreviations used in this paper: 6-AHA, 6-aminohexanoic acid; $\mathrm{Cp}$, carboxypeptidase; GEMSA, guanidinoethylmercaptosuccinic acid; PCI, potato-carboxypeptidase inhibitor; $\mathrm{pCPB}$, plasma carboxypeptidase $\mathrm{B}$; t-PA, tissue-type plasminogen activator. 
fold stimulation of peptidase activity by cobalt, and a threefold preference for lysine over arginine substrates. SDS-PAGE verified the expected composition of a 50- and a 90-kD subunit. "Activated" $\mathrm{Cp} \mathrm{N}$, obtained by purifying $\mathrm{Cp} \mathrm{N}$ in the absence of protease inhibitors, showed partial degradation of the noncatalytic $90-\mathrm{kD}$ subunit and increased specific activity $(+50 \%)$, consistent with published data $(19)$. The activity (lysine substrate) of both $\mathrm{Cp} \mathrm{N}$ preparations on lysine substrate was $>95 \%$ inhibited by $0.1 \mathrm{mM}$ GEMSA, an inhibitor of basic $\mathrm{Cp}$ (22). This concentration of GEMSA had only minimal inhibitory effect on the cleavage of the lysine substrate by $\mathrm{PCPB}$, indicating that the contamination with $\mathrm{PCPB}$-activity was $<5 \%$.

An enriched precursor pCPB (pro-pCPB) fraction was isolated by affinity chromatography of citrated plasma, containing $1 \mathrm{mM}$ PMSF, 5 $\mathrm{mM}$ benzamidine and $5 \mathrm{mM}$ 6-AHA, on plasminogen coupled to $\mathrm{CNBr}-$ activated Sepharose (Pharmacia LKB, Piscataway, NJ) at $3 \mathrm{mg} / \mathrm{ml}$. Bound pCPB was eluted with $50 \mathrm{mM}$ 6-AHA. Absence of $\alpha_{2}$-antiplasmin was shown by the inability of such preparations to inhibit plasmin activity (t-PA $[1 \mu \mathrm{g} / \mathrm{ml}]$ was used to activate plasminogen $[1 \mu \mathrm{M}]$, measured with S-2251). To generate the active pCPB, $200 \mu \mathrm{g} / \mathrm{ml}$ of the preparations were incubated with $10 \mu \mathrm{g} / \mathrm{ml}$ of plasmin for $1 \mathrm{~h}$ at room temperature immediately prior to use in experiments (14), followed by plasmin inhibition with 100 kallikrein inhibiting $\mathrm{U} / \mathrm{ml}$ aprotinin. The activity of pCPB toward the arginine-substrate was inhibited by $1 \mathrm{mM}$ GEMSA $(85 \%)$ and $0.05 \mathrm{mg} / \mathrm{ml}$ potato carboxypeptidase inhibitor (100\%). As the latter inhibitor did not affect Cp N, Cp N was absent in these preparations. For selected experiments, a more highly purified $\mathrm{PCPB}$ preparation, isolated from human plasma with a monoclonal antibody column followed by ion exchange chromatography (Mono Q HR 5/5, Pharmacia), was used. The material was homogenous as judged by SDS-PAGE (23).

Cp-treatment of cells and plasminogen binding analyses. Monocytoid U937 and lymphoid Molt-4 cells were cultured in RPMI, supplemented with $2 \mathrm{mM}$ glutamine and $5 \%$ heat inactivated fetal calf serum. Cell viability was $>95 \%$ as assessed by trypan blue exclusion. Cp N, pCPB or Cp B was incubated in HBSS containing $0.1 \%$ BSA in the presence or absence of $\mathrm{Cp}$-inhibitors for $30 \mathrm{~min}$ at $37^{\circ} \mathrm{C}$ and added to $2 \times 10^{6}$ cells in $100 \mu \mathrm{l}$. After $1 \mathrm{~h}$ at $37^{\circ} \mathrm{C}$, the cells were washed by centrifugation, and ${ }^{125} \mathrm{I}$-plasminogen binding to the cells was assessed (3). When unfractioned plasma was used as the source of $\mathrm{Cp}$, the procedure was slightly modified. Briefly, cells were treated with $5 \mathrm{mM}$ diisopropylflourophosphate and $1 \mathrm{mM}$ PMSF for $30 \mathrm{~min}$ to prevent activation of plasma plasminogen by cell-associated activators. This treatment was effective in neutralizing cell-surface associated plasminogen activating activity (data not shown). Citrated plasma was buffered with $50 \mathrm{mM}$ Hepes, $\mathrm{pH} 7.2$, preincubated with or without $\mathrm{Cp}$-inhibitors for $30 \mathrm{~min}$ at $37^{\circ} \mathrm{C}$, and $100 \mu \mathrm{l}$ were added to $2 \times 10^{6}$ cells for $1 \mathrm{~h}$ at $37^{\circ} \mathrm{C}$. Then, plasma plasminogen bound to the cells was eluted by addition of an equal volume of $200 \mathrm{mM}$ 6-AHA in HBSS for $10 \mathrm{~min}$ at room temperature. In experiments in which ${ }^{125} \mathrm{I}$-plasminogen was added to plasma, this procedure was shown to elute $>99 \%$ of the radioactivity specifically bound to the cells. The cells were washed three times with HBSS before plasminogen binding was assessed (3). Neither of the above treatments caused a loss in cell recovery or viability.

Lysis of whole blood clots. For clot lysis studies, the procedure of Sabovic et al. (24) was adapted. Briefly, blood drawn from healthy volunteers was mixed quickly with tracer amounts, $2 \times 10^{6} \mathrm{cpm} / \mathrm{ml}$, of ${ }^{125}$ I-fibrinogen, isolated and radiolabeled as previously described (25) Aliquots $(500 \mu \mathrm{l})$ were clotted for $3 \mathrm{~h}$ at $37^{\circ} \mathrm{C}$ in glass tubes, and the resulting clots were washed three times for $1 \mathrm{~min}$ with HBSS. Clot associated radioactivity (80-90\% of input) was determined in a $\gamma$ counter and assigned a value of $100 \%$. The clots were then placed in HBSS containing $0.1 \%$ BSA and $1 \mu \mathrm{M}$ plasminogen or buffered citrated plasma. Lysis was initiated by addition of t-PA. Lysis was allowed to proceed at $37^{\circ} \mathrm{C}$ with gentle agitation. Duplicate samples were removed at various time points and counted for released radioactivity to determine the extent of lysis. For selected experiments, plasma was depleted of pro-pCPB by passage over a monoclonal antibody column as described

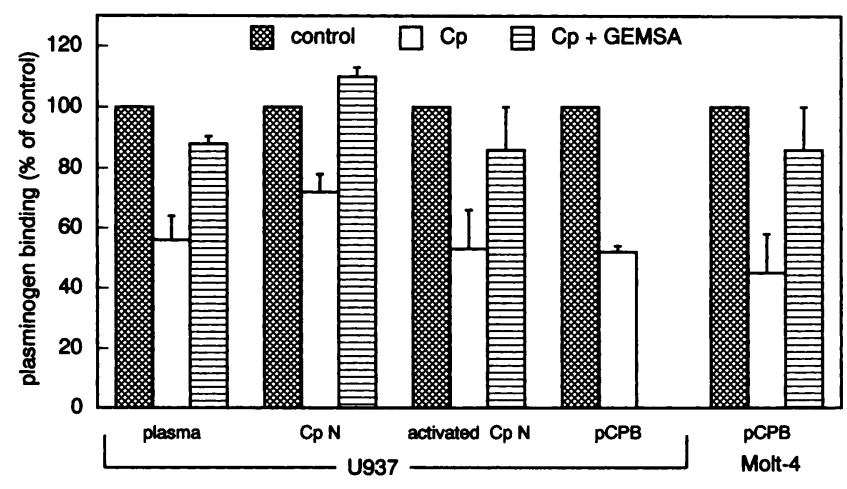

Figure 1. Effect of plasma and isolated plasma Cp on plasminogen binding to cells. U937 or Molt-4 cells were incubated in buffered citrated plasma or with the isolated plasma $\mathrm{Cp}$ in the presence or absence of $0.1 \mathrm{mM}$ GEMSA (Cp N) or $1 \mathrm{mM}$ GEMSA (pCPB) for $1 \mathrm{~h}$ at $37^{\circ} \mathrm{C}$. After washing, plasminogen binding was assessed using $100 \mathrm{nM}{ }^{125} \mathrm{I}$ plasminogen. A buffer control was performed in each experiment and was assigned a value of $100 \%$, and plasminogen binding to Cp-treated cells was expressed as percent of this value. The results are the means \pm SD of 3-6 experiments. Effect of plasma $(n=3, P=0.01)$, Cp N $(n=3, P=0.015)$, "activated" Cp N $(n=6, P=0.0003)$, partially purified pCPB $(n=3, P=0.0004)$, all on U937 cells; and effect of pCPB on Molt-4 cells $(n=3, P=0.036)$ are shown.

(23). As a control, plasma also was passed over an isotype-matched antibody column. $\mathrm{Cp} \mathrm{N}$ activity in these plasma samples was unaffected.

Reagents. Diisopropylflourophosphate-treated carboxypeptidase B (Cp B) was purchased from Sigma Chemical Co., St. Louis, MO; t-PA was from Genentech Inc.; aprotinin was from Miles Inc., Kankakee, IL; plasmin (lysine and 6-AHA-free), GEMSA and potato Cp-inhibitor (PCI) were from Calbiochem, La Jolla, CA.

\section{Results}

The effect of Cp on plasminogen binding to cells. Cells were incubated in plasma or buffer for $1 \mathrm{~h}$ at $37^{\circ} \mathrm{C}$. As shown in Fig. 1 , the cells incubated in plasma consistently exhibited reduced plasminogen binding. In three experiments, the average reduction in plasma was $56 \%$ compared with the buffer control. This effect was not due to occupancy of cellular binding sites by plasma plasminogen as bound plasminogen was eluted with 100 mM 6-AHA before assessing ${ }^{125}$ I-plasminogen binding. More importantly, preincubation of plasma with $1 \mathrm{mM}$ GEMSA, a Cp inhibitor, blocked the inhibitory effect of plasma (Fig. 1). This concentration of GEMSA had no direct effect on plasminogen binding to cells. Likewise, $\mathrm{Cp} \mathrm{N}$, at its plasma concentration (400 U/1, lysine substrate), decreased plasminogen binding to the U937 cells (Fig. 1). The extent of the decrease was $\sim 30 \%$. "Activated" $\mathrm{Cp} \mathrm{N}$, a proteolytic derivative of $\mathrm{Cp} \mathrm{N}$ with enhanced peptidase activity, was somewhat more effective (47\% inhibition, Fig. 1). The reduction in plasminogen binding induced by either $\mathrm{Cp} \mathrm{N}$ preparation was fully blocked by $0.1 \mathrm{mM}$ GEMSA. This effect of GEMSA not only implicates Cp activity in the inhibition of plasminogen binding but also indicates that contaminating $\mathrm{pCPB}$, which is not efficiently inhibited by 0.1 $\mathrm{mM}$ GEMSA, did not contribute to the activity of the $\mathrm{Cp} \mathrm{N}$ preparations. To verify that "activated" $\mathrm{Cp} \mathrm{N}$ did not contain additional proteases that could degrade cell surface proteins, thereby reducing plasminogen binding, surface-labeled U937 cells (5) were treated with "activated" $\mathrm{Cp} \mathrm{N}$ at its plasma 


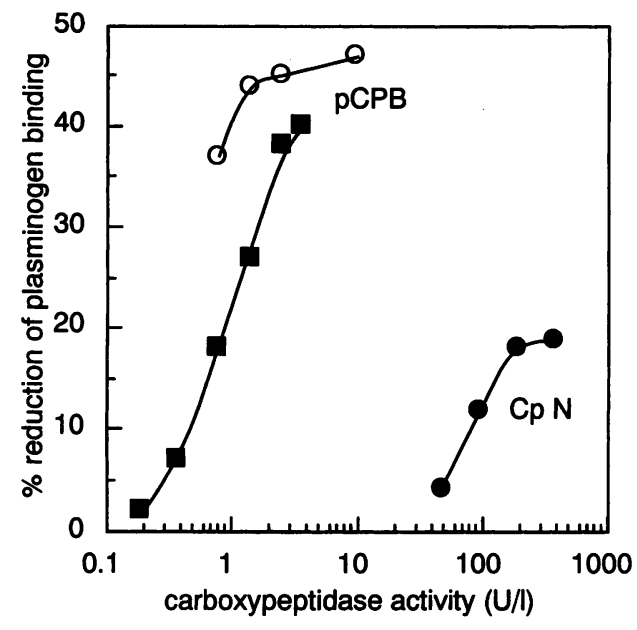

Figure 2. Dose-dependence of the Cp-effect on plasminogen binding to cells. U937 (closed symbols) or Molt-4 (open symbols) cells were incubated with increasing amounts of $\mathrm{Cp}$ as indicated for $1 \mathrm{~h}$. After washing, plasminogen binding was assessed using $100 \mathrm{nM}{ }^{125}$ I-plasminogen. A buffer control was performed in each experiment and was assigned a value of $100 \%$, and percent inhibition of plasminogen binding was plotted against the activity of the enzyme (arginine substrate for pCPB, lysine substrate for $\mathrm{Cp} \mathrm{N}$ ).

concentration ( $400 \mathrm{U} / 1$, lysine substrate) for $1 \mathrm{~h}$ at $37^{\circ} \mathrm{C}$. " Activated' $\mathrm{Cp} \mathrm{N}$ did not cause release of cell-surface radioactivity, whereas a similar concentration of trypsin, $25 \mu \mathrm{g} / \mathrm{ml}$, caused a $35 \%$ reduction of cell-associated radioactivity.

pCPB also caused a reduction in plasminogen binding to cells, $48 \%$ (Fig. 1). Additionally, the effect of pCPB on plasminogen binding to a second cell type, Molt- 4 lymphoid cells, was assessed. A similar reduction in plasminogen binding, 56\%, was observed. If pro-pCPB, without measurable Cp-activity, was added without prior plasmin activation, plasminogen binding was not significantly affected: $5.8 \pm 0.1 \times 10^{5}$ molecules plasminogen bound/cell, compared to $5.3 \pm 0.5 \times 10^{5} \mathrm{~mole}-$ cules/cell for cells incubated in buffer. Furthermore, the reduction of plasminogen binding was not observed in the presence of $1 \mathrm{mM}$ GEMSA, consistent with an effect mediated by $\mathrm{Cp}$ activity. As a point of comparison, pancreatic Cp B $(0.5 \mathrm{mg} /$ $\mathrm{ml}$ ) was used to treat $\mathrm{U} 937$ cells, resulting in similar reduction [48\% $(n=3)]$ in specific plasminogen binding. Thus, plasminogen binding sites were sensitive to inactivation by each $\mathrm{Cp}$. Moreover, the combination of "activated" Cp N (400 U/liter, lysine substrate) and Cp B $(0.5 \mathrm{mg} / \mathrm{ml})$ did not result in a further reduction of plasminogen binding ( $46 \%$ ) compared with to "activated" Cp N alone (46\%), suggesting that these Cp ultimately cleave the same carboxy-terminal lysine residues.

Relative potency of the $C p$ in reducing plasminogen binding to cells. Dose titration experiments were performed to determine the minimal concentration of isolated $\mathrm{Cp}$ required for a maximal reduction in plasminogen binding to U937 cells in $1 \mathrm{~h}$ (Fig. 2). With pancreatic Cp B, the saturating concentration was 500 $\mathrm{mg} /$ liter, corresponding to $100,000 \mathrm{U} / 1$ (arginine substrate) (not shown). Approximately $40 \mathrm{mg} /$ liter or $400 \mathrm{U} /$ liter (lysine substrate) of $\mathrm{Cp} \mathrm{N}$ were required to give maximal effect. Based on activity, $3 \mathrm{U} /$ liter (arginine substrate) were sufficient with pCPB, corresponding to less than $4 \mathrm{mg} /$ liter. A similar saturation curve was obtained for pCPB treatment of Molt- 4 cells (see Fig. 2). Since plasmin can both activate and inactivate
pCPB (14), the pCPB preparation may be a mixture of latent, active and inactive $\mathrm{pCPB}$. Thus, this value for $\mathrm{pCPB}$ could be considerably lower. To compare these concentrations with the concentrations of $\mathrm{Cp}$-activities in plasma, constitutive and latent $\mathrm{Cp}$ was determined in blood samples from seven healthy donors (15). The activity determined in citrated plasma was attributed to $\mathrm{Cp} \mathrm{N}$. The $\mathrm{Cp}$-activity in serum after $1 \mathrm{~h}$ of coagulation at $37^{\circ} \mathrm{C}$ was defined as the sum of $\mathrm{Cp} \mathrm{N}$ and latent ( $\mathrm{Cp} \mathrm{U}$ ) activity, to which pCPB is likely to be a major contributor (16), and we defined latent $\mathrm{Cp}$-activity in blood samples as pCPB. pCPB activity was then calculated by subtracting plasma $\mathrm{Cp}$-activity from serum activity for each blood donor tested. Based on these data, plasma concentrations (average $400 \mathrm{U} /$ liter, lysine substrate) of $\mathrm{Cp} \mathrm{N}$ resulted in maximal reduction of plasminogen binding to cells in our assay system. Much lower concentrations of $\mathrm{pCPB}$ ( $3 \mathrm{U} / \mathrm{liter}$ ) were required for maximal effect on cellular plasminogen binding. Plasma concentrations of inducible Cp ranged from $15-50$ U/liter. Thus, at $<20 \%$ of plasma concentration, an effect on plasminogen binding is still predicted. In summary, $\mathrm{pCPB}$ is the more potent $\mathrm{Cp}$ in reducing plasminogen binding to cells, with pCPB $>\mathrm{Cp} \mathrm{N} \gg \mathrm{Cp} \mathrm{B}$. Cp $\mathrm{B}$ is unlikely to contribute to the plasma $\mathrm{Cp}$-activity because of the high concentrations required and its absence from normal plasma (26).

Effect of carboxypeptidases on whole blood clot lysis. The carboxy-terminal lysines in partially degraded fibrin enhance plasminogen activation and accelerate fibrinolysis (12). Plasma Cp could remove these carboxy-terminal lysines and, thereby, blunt fibrin degradation $(11,12)$. To test this possibility, the lysis of whole blood clots was followed in the absence and presence of highly purified, pro-pCPB or Cp N. Blood clots, formed with tracer ${ }^{125}$ I-fibrinogen, were placed in buffer with t-PA and plasminogen. In this experimental setting, pro-pCPB is activated by the generated plasmin. These clots are stable, both in plasma or buffer, with $<5 \%$ lysis in $30 \mathrm{~h}$. Over an observation period of $3 \mathrm{~h}$, lysis was significantly inhibited by the addition of pro-pCPB (Fig. $3 \mathrm{~A}$ ). Consistent with an indirect inhibitory effect via the clot, $\mathrm{pCPB}$ did not inhibit plasmin activity, measured with S2251 using the same concentrations of plasminogen and t-PA in the absence of a clot. The inhibition of clot lysis was overcome by addition of PCI, a specific inhibitor of $\mathrm{pCPB}$, indicating that the inhibition of clot lysis was dependent on the catalytic activity of pCPB. Similar results were obtained in three separate experiments using blood from two different donors. The delay in the inhibitory effect of propCPB may reflect the time required for its activation to pCPB. Plasma concentrations of $\mathrm{Cp} \mathrm{N}$, on the other hand, inhibited clot lysis only marginally under these conditions: after $1.5 \mathrm{~h}$, the extent of lysis was $75 \%$, both in the absence and presence of $\mathrm{Cp} \mathrm{N}$. We next explored if inhibition of pCPB by PCI influenced fibrinolysis in plasma. As shown in Fig. $3 \mathrm{~B}$, addition of PCI to plasma resulted in a significant acceleration of clot lysis, consistent with Fig. $3 \mathrm{~A}$. Spontaneous lysis $(<5 \% / 30 \mathrm{~h})$ was not affected by PCI, indicating that the inhibitor preparation does not contain fibrinolytic activity. $\mathrm{Cp} \mathrm{N}$ inhibition $(0.1 \mathrm{mM}$ GEMSA), on the other hand, had no effect on clot lysis in plasma by t-PA (not shown). To more directly show that this stimulatory effect was, indeed, due to inhibition of pCPB, we depleted plasma of pCPB by passage over a column coupled with a monoclonal antibody against $\mathrm{pCPB}$ (23). As shown in Fig. $3 C$, pCPB-depletion resulted in a accelerated clot lysis compared to plasma passed over a column coupled with an 


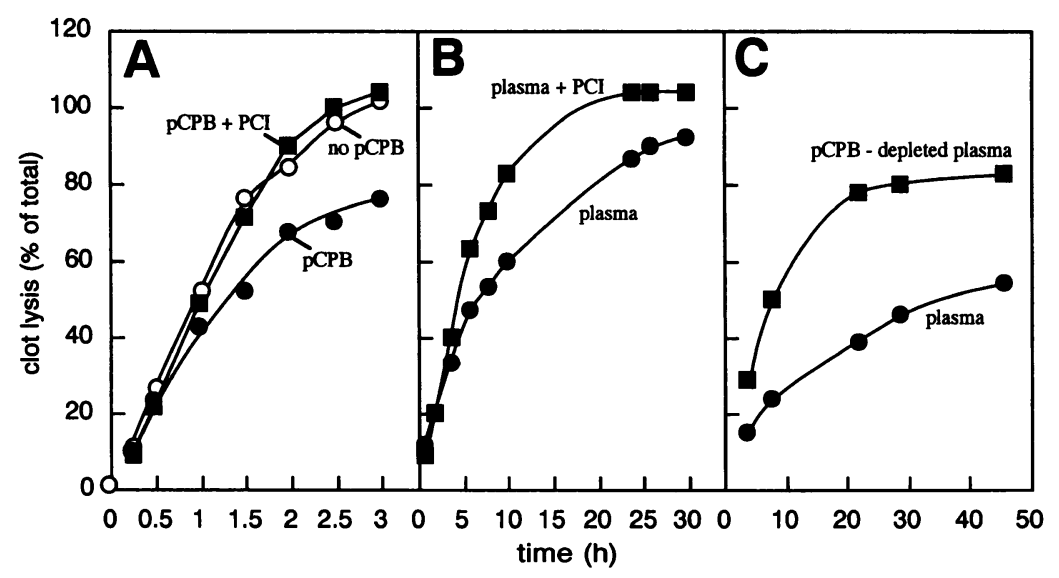

Figure 3. Effect of plasma Cp on clot lysis. Whole blood clots, labeled with ${ }^{125} \mathrm{I}$-fibrinogen, were incubated with $1 \mu \mathrm{M}$ plasminogen in HBSS $(A)$ or buffered (50 $\mathrm{mM}$, Hepes pH 7.2) citrated plasma $(B$ and $C$ ) and tPA. Clot lysis was followed by measuring the release of radioactivity into the supernatant fraction at the indicated time points. $(A)(\mathrm{t}-\mathrm{PA}$ at $1 \mu \mathrm{g} / \mathrm{ml}) ;(\bullet)$ pro-pCPB highly purified $(20 \mu \mathrm{g} / \mathrm{ml}$, equivalent of $15 \mathrm{U} / 1) ;(\square)$ pro-pCPB and $100 \mu \mathrm{g} / \mathrm{ml}$ PCI; and $(O)$ control (t-PA and plasminogen alone). (B) (t-PA at $0.1 \mu \mathrm{g} / \mathrm{ml})$; plasma without $(\bullet)$ or with $(\square) 20 \mu \mathrm{g} / \mathrm{ml} \mathrm{PCI}$; $(C)$ (tPA at $50 \mu \mathrm{g} / \mathrm{ml}) ;(\square)$ pCPB antibody-depleted plasma; or $(\bullet)$ control antibody-treated plasma. isotype-matched control antibody. To address the basis for the differential effect of $\mathrm{pCPB}$ and of $\mathrm{Cp} \mathrm{N}$ on clot lysis, we used partially plasmin digested whole blood clots (11), treated them with plasma concentrations of either $\mathrm{Cp} \mathrm{N}$ or pCPB, and then assessed binding of ${ }^{125} \mathrm{I}$-plasminogen to these clots. Nonspecific binding was determined in the presence of $200 \mathrm{mM}$ 6-AHA. While treatment with pCPB resulted in extensive removal $(>90 \%$ ) of specific binding sites, Cp N removed $<50 \%$ of the specific binding. Thus, as with plasminogen binding to cells, $\mathrm{Cp} \mathrm{N}$ is less effective in removing carboxyterminal lysyl residues from fibrin surfaces.

\section{Discussion}

In this study, we show that plasma $\mathrm{Cp}$ function as previously unrecognized regulators of the plasminogen system. Plasma $\mathrm{Cp}$ are capable of reducing plasminogen binding to cells and counteracting the plasmin-induced up-regulation of cellular plasminogen binding sites. Furthermore, the plasminogen binding $\mathrm{Cp}$, pCPB, inhibits whole blood clot lysis, implicating this enzyme in the regulation of fibrinolysis. These data support the model depicted in Fig. 4. Cells and fibrin express a constitutive plas- minogen binding capacity. Proteolysis of cell surfaces and fibrin by plasmin and other proteinases can generate new carboxyterminal lysines (6-11). These residues support additional plasminogen binding, which, in turn, facilitates further plasminogen activation. Controlling this up-regulation of plasminogen binding are the plasma $\mathrm{Cp}$. By removing the carboxy-terminal lysines, the $\mathrm{Cp}$ down-regulate plasminogen binding and activation on the surface of cells and fibrin, thereby dampening proteolysis. Thus, the $\mathrm{Cp}$ complete a proteolytic amplification loop, returning plasminogen binding to a basal state.

Both $\mathrm{Cp} \mathrm{N}$ and pCPB suppressed plasminogen binding to cells. Compared on the basis of activity towards small peptide substrates, pCPB was more potent in reducing plasminogen binding to cells than $\mathrm{Cp} \mathrm{N}$ and $\mathrm{Cp} \mathrm{B}$. pCPB also was effective in reducing the rate of fibrinolysis, whereas $\mathrm{Cp} \mathrm{N}$ was not. pCPB is activated by both plasmin and thrombin and interacts directly with plasminogen (14). Accordingly, it is tempting to speculate that $\mathrm{pCPB}$ functions as a thrombin-activated stabilizer of blood clots by dampening fibrinolysis. In addition, during ongoing fibrinolysis, more pCPB would be activated by plasmin and serves as a "brake" on the amplification of proteolysis induced by plasmin-mediated generation of carboxy-terminal

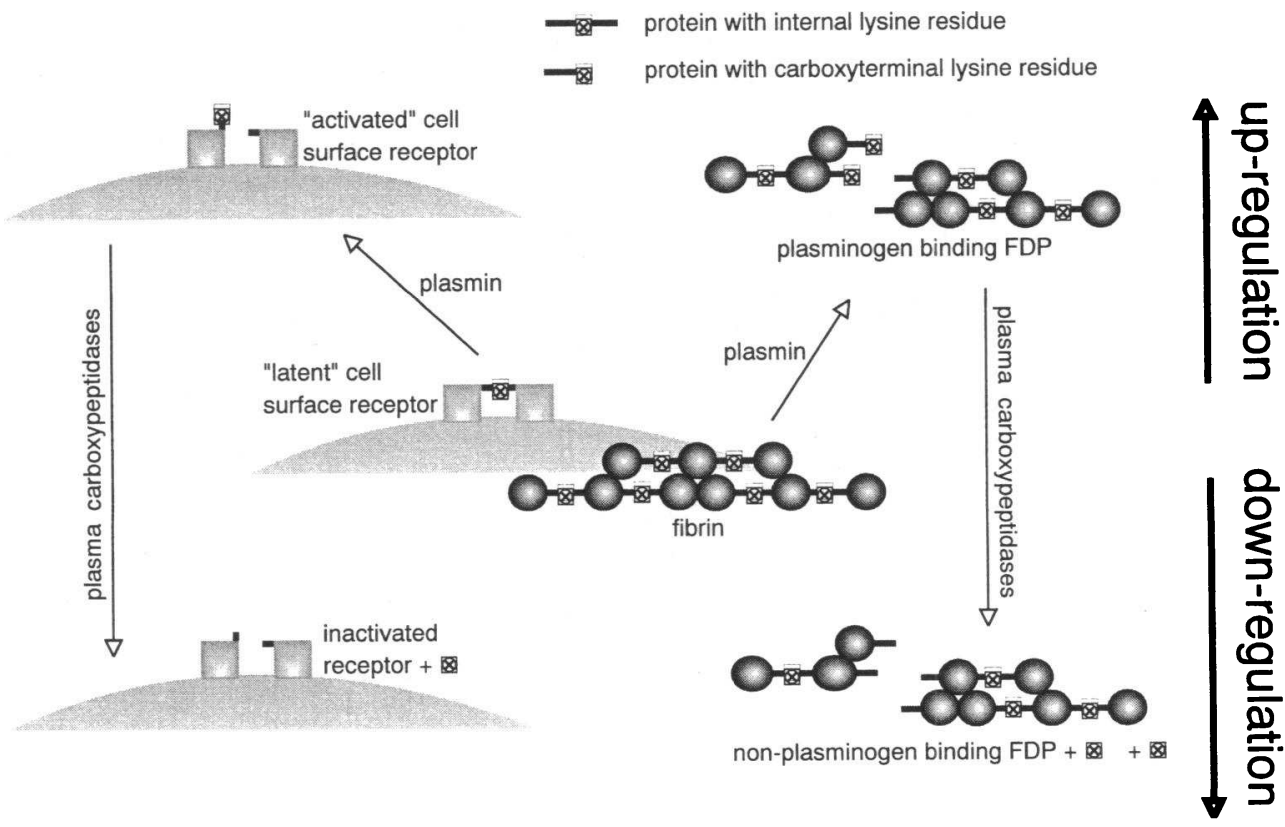

Figure 4. Model for the role of plasma proteinases in the modulation of plasminogen binding to cell and fibrin surfaces. Carboxyterminal lysines on cells and fibrin, particularly partially degraded fibrin, can serve as plasminogen binding sites by interacting with the lysine binding sites of plasminogen. Proteinases, such as plasmin, can generate such carboxy-terminal lysines, thereby upregulating plasminogen binding sites. Plasma carboxypeptidases, such as $\mathrm{Cp} \mathrm{N}$ and $\mathrm{pCPB}$, cleave carboxy-terminal lysines. Thus, the carboxypeptidases down-regulate plasminogen binding sites and dampen fibrinolysis and cell-associated proteolysis. 
lysine residues on cell surfaces $(6-8)$ and fibrin $(10,11)$. Although $\mathrm{Cp} \mathrm{N}$ appears to be considerably less potent than pCPB, particularly in affecting fibrinolysis, it may still regulate the availability of carboxy-terminal lysine residues in the absence of coagulation and plasminogen activation. This constitutive removal of plasminogen binding sites by $\mathrm{Cp} \mathrm{N}$ may explain why freshly-isolated teukocytes express a two orders of magnitude lower number of plasminogen binding sites compared to cultured cells $(27,28)$. In addition, limited proteolysis of $\mathrm{Cp} \mathrm{N}$ increases its activity toward peptide substrates and plasminogen binding sites, suggesting that plasmin or other plasma proteases involved in hemostasis may "activate" $\mathrm{Cp} \mathrm{N}$. A question yet to be resolved is whether all inducible $\mathrm{Cp}$-activity $(\mathrm{Cp} \mathrm{U})$ is attributable to $\mathrm{pCPB}$, as proposed in ref. (16). Alternatively, other inducible $\mathrm{Cp}$ may be present in plasma that, in concert with $\mathrm{pCPB}$ and $\mathrm{Cp} \mathrm{N}$, regulate the availability of plasminogen binding sites in the vasculature.

In clot lysis experiments, $\mathrm{pCPB}$ directly affected the kinetics of fibrinolysis. The concentration of $\mathrm{PCPB}$ used in the clot lysis experiments would maximally generate $15 \mathrm{U} / \mathrm{l} \mathrm{Cp}$-activity (based upon the arginine substrate with plasmin as the propCPB activator), which falls within the range of inducible Cpactivity in blood. Considerable variation of latent $\mathrm{Cp}$-activity, both in healthy individuals and in inflammatory disease (29) has been observed. Thus, individual differences in clot lysis kinetics may be linked to the potency of the Cp-system. This possibility further suggests that selective modulation of pCPB activation and activity might be an approach to enhance the efficacy of thrombolytic therapy. Cp N was ineffective in clot lysis experiments, which may be a result of its reduced ability to remove carboxy-terminal lysyl residues from the clot-surface and/or its inactivation by plasmin (20).

\section{Acknowledgments}

This work was supported by National Institutes of Health grant HL17964. A. Redlitz was the recipient of a Postdoctoral Fellowship of the American Heart Association, Northeast Ohio Affiliate.

\section{References}

1. Vassalli, J. -D., A. -P. Sappino, and D. Belin. 1991. The plasminogen activator/plasmin system. J. Clin. Invest. 88:1067-1072.

2. Collen, D., and H. R. Lijnen. 1992. Basic and clinical aspects of fibrinolysis and thrombolysis. Blood. 78:3114.

3. Plow, E. F., D. E. Freaney, J. Plescia, and L. A. Miles. 1986. The plasminogen system and cell surfaces: Evidence for plasminogen and urokinase receptors on the same cell type. J. Cell Biol. 103:2411-2420.

4. Wiman, B., and D. Collen. 1978. On the kinetics of the reaction between human antiplasmin and plasmin. Eur. J. Biochem. 84:573-578.

5. Miles, L. A., C. M. Dahlberg, J. Plescia, J. Felez, K. Kato, and E. F. Plow. 1991. Role of cell-surface lysines in plasminogen binding to cells: identification of alpha-enolase as a candidate plasminogen receptor. Biochemistry. 30:16821691.

6. Camacho, M., M. -C. Fondanèche, and P. Burtin. 1989. Limited proteolysis of tumor cells increases their plasmin-binding ability. FEBS Lett. 245:21-24.

7. Gonzalez-Gronow, M., S. Stack, and S. V. Pizzo. 1991. Plasmin binding to the plasminogen receptor enhances catalytic efficiency and activates the receptor for subsequent ligand binding. Arch. Biochem. Biophys. 286:625-628.

8. Hajjar, K. A., A. T. Jacovina, and J. Chacko. 1994. An endothelial cell receptor for plasminogen/tissue plasminogen activator. I. Identity with annexin II. J. Biol. Chem. 269:21191-21197.

9. Christensen, U. 1985. C-terminal lysine residues of fibrinogen fragments essential for binding to plasminogen. FEBS Lett. 182:43-46.

10. Harpel, P. C., T. -S. Chang, and E. Verderber. 1985. Tissue plasminogen activator and urokinase mediate the binding of Glu-plasminogen to plasma fibrin I. J. Biol. Chem. 260:4432-4440.

11. Fleury, V., and E. Angles-Cano. 1991. Characterization of the binding of plasminogen to fibrin surfaces: the role of carboxy-terminal lysines. Biochemistry. 30:7630-7638.

12. Pannell, R., J. Black, and V. Gurewich. 1988. Complementary modes of action of tissue-type plasminogen activator and pro-urokinase by which their synergistic effect on clot lysis may be explained. J. Clin. Invest. 81:853-859.

13. Skidgel, R. A. 1988. Basic carboxypeptidases: regulators of peptide hormone activity. Trends Pharmacol. Sci. 9:299-304.

14. Eaton, D. L., B. E. Malloy, S. P. Tsai, W. Henzel, and D. Drayna. 1991 Isolation, molecular cloning, and partial characterization of a novel carboxypeptidase B from human plasma. J. Biol. Chem. 266:21833-21838.

15. Hendriks, D., S. Scharpe, M. van Sande, and M. P. Lommaert. 1989. Characterization of a carboxypeptidase in human serum distinct from carboxypeptidase N. J. Clin. Chem. Clin. Biochem. 27:277-285.

16. Wang, W., D. F. Hendriks, and S. S. Scharpé. 1994. Carboxypeptidase $\mathrm{U}$, a plasma carboxypeptidase with high affinity for plasminogen. J. Biol. Chem. 269:15937-15944.

17. Plummer, T. H., Jr. and M. T. Kimmel. 1980. An improved spectrophotometric assay for human plasma carboxypeptidase N. Anal. Biochem. 108:348353.

18. Skidgel, R. A., and E. G. Erdos. 1984. Carboxypeptidase N (arginine carboxypeptidase). In Methods of Enzymatic Analysis. Verlag Chemie, Weinheim, Germany. 60-72.

19. Plummer, T. H., Jr. and M. Y. Hurwitz. 1978. Human plasma carboxypeptidase N. Isolation and characterization. J. Biol. Chem. 253:3907-3912.

20. Levin, Y., R. A. Skidgel, and E. G. Erdos. 1982. Isolation and characterization of the subunits of human plasma carboxypeptidase N (kininase I). Proc. Natl. Acad. Sci. U.S.A. 79:4618-4622.

21. Skidgel, R. A. 1995. Human carboxypeptidase N (lysine carboxypeptidase). Methods Enzymol. 248:653-663.

22. McKay, T. J. and T. H. Plummer, Jr. 1978. By-product analogues for bovine carboxypeptidase B. Biochemistry. 17:401-405.

23. Tan, A. K., and D. L. Eaton. 1995. Activation and characterization of procarboxypeptidase B from human plasma. Biochemistry. 34:5811-5816.

24. Sabovic, M., H. R. Lijnen, D. Keber, and D. Collen. 1989. Effect of retraction on the lysis of human clots with fibrin specific and non-fibrin specific plasminogen activators. Thromb. Haemost. 62:1083-1087.

25. Marguerie, G. A., T. S. Edgington, and E. F. Plow. 1980. Interaction of fibrinogen with its platelet receptor as part of a multistep reaction in ADP-induced platelet aggregation. J. Biol. Chem. 255:154-161.

26. Delk, A. S., P. R. Durie, T. S. Fletcher, and C. Largman. 1985. Radioimmunoassay of active pancreatic enzymes in sera from patients with acute pancreatitis. Clin. Chem. 31:1294-1300.

27. Miles, L. A., and E. F. Plow. 1987. Receptor mediated binding of the fibrinolytic components, plasminogen and urokinase, to peripheral blood cells. Thromb. Haemost. 58:936-942.

28. Felez, J., L. A. Miles, J. Plescia, and E. F. Plow. 1990. Regulation of plasminogen receptors on human monocytes and monocytoid cells. J. Cell Biol. 111:1673-1683.

29. Campbell, W., K. Yonezu, T. Shinohara, and H. Okada. 1990. An arginine carboxypeptidase generated during coagulation is diminished or absent in patients with rheumatoid arthritis. J. Lab. Clin. Med. 115:610-612. 